Anuario Latinoamericano

Ciencias Políticas

y Relaciones Internacionales

vol. 3, 2016

pp. 183-194

\section{The relations between Latin America and the Islamic State of Iraq and the Levant}

DOI: $10.17951 / \mathrm{al} .2016 .3 .183$

\section{Las relaciones entre América Latina y el Estado Islámico de Irak y del Levante}

\author{
Edyta Chwiej \\ JAGIELLONIAN UNIVERSITY \\ CRACOW, POLAND \\ $\triangle$ edyta.chwiej@uj.edu.pl
}

\begin{abstract}
Terrorism is one of the most important problems facing the world. The Islamic State of Iraq and the Levant is one of the most dangerous jihadist groups. It controls large parts of territory in Syria and Iraq. In June 2014 the group declared the creation of a caliphate and shortened its name to Islamic State to reflect its expansionist ambitions.

This article presents the short history of ISIS, its structure and the source of financing. Moreover, it describes the relations between the Islamic State and the Latin America and the Caribbean region. Although there are not many links, we may say that they really exist. The future relations depend mainly on effectiveness of the the international community in its fight against the expansion of ISIS.
\end{abstract}

KEYWORDS: ISIS, Latin America and the Caribbean, terrorism.

\section{RESUMEN}

El terrorismo es uno de los desafíos más importantes que encara el mundo. El Estado Islámico de Irak y del Levante es uno de los grupos yihadistas más peligrosos. Este grupo controla una gran parte del territorio de Siria e Irak. En junio de 2014 el grupo declaró la creación del califato y cambió su nombre al de Estado Islámico para reflejar sus ambiciones expansionistas.

Este artículo presenta la breve historia de ISIS, su estructura y la fuente de financiación. Además, describe las relaciones entre el Estado Islámico y la región de América Latina y el Caribe. Aunque no hay muchos vínculos, pero algunos sí existen. Las futuras relaciones dependerán principalmente de la efectividad de la comunidad internacional en la lucha contra la expansión de ISIS.

PALABRAS CLAVE: ISIS, América Latina y el Caribe, terrorismo. 


\section{Introduction}

Terrorism is one of the most important problems facing the world, especially after the attacks of September 11,2001. Some politicians and scientists say the Islamic State of Iraq and the Levant (ISIS) might be more dangerous than al-Qaeda. The group constitutes a very big threat to peace and security of the world, not only of the Middle East. The main goal of the present article is to identify any relationships between the ISIS and the Latin America and the Caribbean region.

\section{History of ISIS}

The members of the Islamic State of Iraq and the Levant proclaimed an Islamic caliphate in an area straddling Iraq and Syria in June 2014 and named its leader Abu Bakr al-Baghdadi as the caliph. The group has had various names since it was founded in the 90s. The founder of the group was Jordanian Abu Musab al-Zarqawi (Cockburn 2015: 13).

Since the beginning of the twentieth century, the organization has been operating in Iraq under the name Jama'at al-Tawhid wal-Jihad (Organization of Monotheism and Jihad). The organization took part in the Iraq War (20032011). In 2004, al-Zarqawi pledged allegiance to al-Qaeda leader, Osama bin Laden, and the group was commonly known as al-Qaeda in Iraq (the full name was Tanzim Qaidat al-Jihad fi Bilad al-Rafidayn - Organization of Jihad's Base in Mesopotamia). It is believed that the organization was responsible for some of the most spectacular and brutal attacks of that conflict (Hall 2015: 30-31).

Zarqawi was killed in a U.S. air strike in June 2006. In the same year the group changed the name to Islamic State of Iraq. The situation of the group got worse due to the activity of the Sons of Iraq and by the loss of several of its senior leaders in attacks made by U.S. and Iraqi forces. ${ }^{1}$ Sons of Iraq was the coalition of the Sunni tribes of western Iraq which turned against the Islamic State of Iraq because of cruel treatment of civilians. But in the 2008, Nouri Kamil Mohammed Hasan al-Maliki, Prime Minister of Iraq, began marginalizing Sunnis and Kurds. Many effective commanders who had been fighting against al Qaeda in Iraq were forced to resign in the face of lack of soldiers' pay or were reassigned to desk jobs and replaced with al-Maliki loyalists, mainly Shiite. The same applied to the soldiers fighting in the army of Saddam Hussein. Many of soldiers dismissed by Prime Minister al-Maliki joined the Islamic State of Iraq (Laurent 2015: 114-115).

Abu Bakr al-Baghdadi (real name Ibrahim Awwad Ibrahim Ali al-Badri al-Samarrai) was appointed the new leader of the Islamic State of Iraq in June 2010, after the death of the previous leader, Abu Omar al-Baghdadi (Hall

1 Z. Laub, The Islamic State, The Council on Foreign Relations, http://www.cfr.org/iraq/ islamic-state/p14811 (access 10.03.2016) 
2015: 42). The repressions of Sunnis carried out by the administration of Prime Minister al-Maliki under the guise of fighting al-Qaeda and remnants of the Ba th Party regime have contributed to the growing ISIS support. ${ }^{2}$

The war in Syria, which began in 2011, provided new opportunities for Islamic State of Iraq, whose fighters could easily cross from Iraq into eastern Syria. In March 2011, within the context of the Arab Spring, the protests against the Syrian President Bashar Hafez al-Assad began, after the arrest and torture of some teenagers who painted revolutionary slogans on a school wall. Syrians were divided between supporters and opponents of the President Assad regime. There were many violent clashes between Alawite-dominated government forces, militias and the opposition groups. ${ }^{3}$

In August 2011, al-Baghdadi began sending the members of his group to Syria, under the leadership of Abu Muhammad al-Juliani, with the mission to establish an organization there. Jabhat al-Nusra (Jabhat al-Nusra li Ahl as-Sham; The Support Front for the People of Al-Sham) was formed in 2012. It is more commonly known as the al-Nusra Front. Jabhat al-Nusra took control of the local groups and grew rapidly into an influential fighting force, with popular support among Syrians opposed to the Assad government (Hall 2015: 65-67).

In 2013, al-Baghdadi announced his intention to take control of the alNusra Front and combine his forces in Iraq and Syria under the name Islamic State of Iraq and Al-Sham. The merger was rejected by the Jabhat al-Nusra and resulted in open fighting. Al-Juliani asked the head of al-Qaeda, Ayman Mohammed Rabie al-Zawahiri, for mediation, but finally the group was split and many of al-Nusra fighters joined the al-Bagdadi group (Hall 2015: 69).

Islamic State of Iraq and Al-Sham quickly established a zone of exclusive authority in eastern areas of Syria and made its headquarter in Al-Raqqah. From its stronghold the group of al-Bagdadi expanded outward, launching successful offensives in both Syria and Iraq. In Syria the group has been controlling Al-Raqqa, part of Homs province, parts of the countryside around Aleppo and the small area in the south of Damascus. In Iraq, it has been occupying Mosul, the second largest city in the country, and Ramadi, the capital of Anbar province. ${ }^{4}$ On the 29 th of June 2014 the group announced the establishment of a caliphate and declared its chief, Abu Bakr al-Baghdadi, the caliph and leader for Muslims everywhere. ${ }^{5}$

2 Islamic State in Iraq and the Levant (ISIL), Encyclopedia Britannica, http://www.britannica.com/topic/Islamic-State-in-Iraq-and-the-Levant, access: 10.03.2016.

3 Syria: The story of the conflict, BBC, 11.03.2016, http://www.bbc.com/news/world-middleeast-26116868, access: 12.03.2016.

${ }^{4}$ ISIS under airstrikes - a guide in maps, "The Guardian”, 02.12.2015, http://www.theguardian.com/world/ng-interactive/2015/dec/02/isis-territory-under-airstrikes-guide-in-maps, access: 14.03.2016.

5 Sunni rebels declare new 'Islamic caliphate', "Al-Jazzera", 30.06.2014, http://www.aljazeera. com/news/middleeast/2014/06/isil-declares-new-islamic-caliphate-201462917326669749.html, access: 14.03.2016.
The relations between Latin America and the Islamic State of Iraq and the Levant

Edyta Chwiej 


\section{The structure of ISIS}

There are a few different names used in relation to the group of al-Baghdadi. Many authors and publicists use the acronym ISIS, which comes from the name Islamic State in Iraq and al-Sham. The term Al-Sham was created to describe the area between the Mediterranean and the Euphrates, Anatolia (in Turkey) and Egypt. It was the historical province, organized after the Muslim conquest of Syria in the first mid of the 7th century (Irshaid 2015). According to Benjamin Hall, the addition of the word Al-Sham to the name Islamic State in Iraq was a signal that the group is planning further expansion and conquest of that region (Hall 2015: 17).

Many of American and British officials use the acronym ISIL - the acronym of Islamic State in Iraq and the Levant. The word Levant refers to the historical name of the area in the eastern Mediterranean (the land where the sun rises). It includes the territory of Syria, Lebanon, Israel, Palestine and Jordan (Osborne 2015). But according to other sources, it is the area composed of Syria, Lebanon, Jordan, Turkey and part of Egypt (Hall 2015: 17).

On the 29th of June 2014, the group announced it was dropping the last two letters of the acronym ISIS and instead should be referred to as the IS Islamic State. Moreover, the Arabic-speaking world and the governments of France and the United Kingdom use the acronym DAESH which has also the pejorative overtone. This acronym is formed from the first letters of the Arabic name of the organization (Ad-Daula al-Islamijja fi al-Irak wa-asz-Szam), but it also means "be trampled" or "broken in the dust" (Osborne; Irshaid; Hall 2015: 18).

Abu Bakr al-Baghdadi is the head of the Islamic State. Little is known of his life. Al-Baghdadi was born in Samarra (Iraq) in 1971. He probably was a cleric in a mosque in Samarra around the time of the US-led invasion in $2003 .{ }^{6}$ According to some sources, he obtained the MA and PhD from the Islamic University in Baghdad (Withnall, Blair 2015). In response to the U.S. invasion of Iraq in 2003, al-Baghdadi founded, with other militants, the organization Jamaat Ansar al-Sunnah (Assembly of the Helpers of Sunnah) (Laurent 2015: 110). Some reports say that al-Baghdadi was captured by U.S. forces in 2005 and imprisoned at the U.S. military prison Camp Bucca in Iraq until 2009 (Hall 2015: 39). Others assert that he was arrested in February 2004, but he was released in December of the same year (Laurent 2015: 112). Abu Bakr al-Baghdadi was appointed the new leader of the Islamic State of Iraq in June 2010. In October 2011, the US officially designated Baghdadi as terrorist and offered 10 million dollars reward for information about him.

ISIS is led by al-Baghdadi, who makes the most important decisions and is responsible for the policy of the group. But formally he reports to the Shura

6 Profile: Abu Bakr al-Baghdadi, 15.05.2015, http://www.bbc.com/news/world-middle-east -27801676, access: 17.03.2016. 
Council. The nine-member (according to other sources even eleven-member) Shura Council is responsible for making sure lower councils adhere to ISIS's religious doctrine. It is also responsible for relaying al-Baghdadi's orders through the rest of the organization. ${ }^{7}$ Moreover, the Shura Council has the power to force al-Baghdadi to step down, if he deviates from the ISIS doctrine.

The Shariah Council also plays an important role in the ISIS structure. This six-member body is responsible for enforcing its interpretation of shariah in controlled area. The Shariah Council creates a shariah police force and shariah courts to enforce its interpretation of Islamic law in the occupied territories. ${ }^{8}$

Al-Baghdadi, his Cabinet advisers and his two key deputies: Abu Ali alAnbari and Abu Muslim at-Turkumani (Fadil Abd Allah al-Hijali) comprise the executive branch of the government. Turkmani was elected as the governor of twelve regions in Iraq and al-Anbari, respectively, in Syria. These leaders of ISIS are Iraqi and served under Saddam Hussein (Thompson, Shubert 2015). According to some sources, they were detained with Abu Bakr al-Baghdadi in Camp Bucca (Klausner 2015).

The deputies oversee ministry-like councils:

- Financial Council: responsible for oil sales, weapons and other revenue,

- Leadership Council: responsible for drafting laws and key policies,

- Military Council: responsible for military and defense operations,

- Legal Council: taking decisions on executions and recruitment,

- Fighters Assistance Council: responsible for aid and accommodation of foreign fighters,

- Security Council: responsible for security oversight of ISIS's territory,

- Intelligence Council: responsible for intelligence activities,

- Media Council: preparing ISIS's media strategy (Thompson, Shubert 2015). ${ }^{9}$

The size of territory occupied by the Islamic State in September 2014 was comparable to the size of Great Britain (Noack 2014). But according to press reports, the group lost $40 \%$ of Iraq territory and 20\% in Syria as a result of international air strikes in December 2015 (Dearden 2016). It is estimated that 10 million people live under ISIS control. ${ }^{10}$

ISIS is a very specific organization because it does not need outside funding. Audrey Kurth Cronin notes that holding territory has allowed the group to build a self-sustaining financial model unthinkable for most terrorist groups (Kurth Cronin 2015). The Islamic State's revenue is estimated from 1 to 3 million dollars a day (Swanson 2015). Revenue comes mainly from the extraction and export of oil from the oilfields in Syria and Iraq. The ISIS mostly

7 ISIS. Organizational Structure, Counter Extremism Project, http://www.counterextremism.com/threat/isis, access: 18.03.2016.

8 Ibidem.

9 ISIS. Organizational Structure.., op. cit.

${ }^{10}$ Islamic State group: Crisis in seven charts, 15.03.2016, http://www.bbc.com/news/worldmiddle-east-27838034, access: 18.03.2016.
The relations between Latin America and the Islamic State of Iraq and the Levant

Edyta Chwiej 
refines oil in small, mobile refineries and sells it illegally to Jordan, Turkey and the Assad regime (Kurth Cronin 2015). The other sources of income are: wealthy donors, taxes from the people who live on the controlled territory, kidnapping for ransom, seizing branches of banks in Iraq, sales of antiquities from Syria and human trafficking (mainly women and girls) (Swanson 2015).

According to estimates by Ryan Mauro, around 42 million people in the Arab world support ISIS, mainly in Syria, Iraq, Palestinian Territories, Tunisia, Egypt and Saudi Arabia (Mauro 2015). Moreover ISIS has received mixed levels of support from the some jihadi groups such as Al-Qaeda in the Arabian Peninsula (Yemen), Al-Qaeda in the Islamic Maghreb, Ansar Bait al-Maqdis (Egypt), Boko Haram (Jamāat Ahl as-Sunnah lid-Da'wah wa'l-Jihād, Nigeria), Ansar al-Sharia (Tunisia), Tehreek-e-Khilafat (Pakistan), Jund al-Khalifah fi Ard al-Jazayer (Algieria), Abu Sayyaf (Philippines), Mujahidin Indonesia Timur and Harakat al-Shabaab al-Mujahideen (Somalia) (Alexander, Alexander 2015 , p. 110). It is worth mentioning that the Islamic State has also strengthened its positions in Libya since 2014 (Jones, Saleh 2016).

\section{Relations with Latin America and Caribbean}

In the opinion of Israel López, the Mexican journalist, the Islamic State is, on the one hand, far from Latin America and Caribbean but, on the other, very close. It is far because ISIS operates mainly in the Middle East and in the North Africa region. However, the Latin American countries create conditions conducive to supporting terrorist groups through the provision of funds (López 2015). According to the U. S. Department of State, the external terrorist groups do not currently menace the region and the main terrorist threat in the Western Hemisphere can come from the Revolutionary Armed Forces of Colombia (FARC). The Latin American governments recognize the potential threat that terrorism represents and improve their counterterrorism capabilities and border security. But for some countries such things like corruption, weak government institutions, insufficient interagency cooperation, weak or non-existent legislation, and lack of resources significantly impair the ability to fight against the terrorism. Moreover, the governments should investigate possible connections between terrorist organizations and transnational criminal organizations. ${ }^{11}$

Over the past several years policymakers have been concerned about Iran's increasing activities in Latin America and its ties to the Islamic group Hezbollah. Tri-Border Area of Argentina, Brazil and Paraguay is considered to be the main area of the activity of this group. The presence of Hezbollah members or sympathizers has also been noted in other areas of Latin America, such as

${ }^{11}$ Country Reports on Terrorism 2014, U.S. Department of State, http://www.state.gov/j/ct/ rls/crt/2014/index.htm, access: 26.03.2016. 
Chile (Iquique), Colombia (Maicao), Venezuela (Margarita Island) and Panama. The group's sympathizers support the Hezbollah, using the Tri-Border Area to engage in illicit activity for profit (including arms and drug trafficking) and solicit donations from the local communities. ${ }^{12}$ Although the current presence of ISIS in Latin America is low, the members of this group may, in the future, take advantage of the opportunities of this support.

Some experts are afraid that the drug cartels in Mexico can also collaborate with the terrorist organizations. Cartels and terrorist groups can use the same intermediaries for obtaining weapons, money laundering and moving illegal products across the borders. In April 2015, the organization Judicial Watch informed that the Islamic State established its cells in Mexico near the U.S. border, in an area known as Anapra (near Ciudad Juárez) and in Puerto Palomas. According to the Judicial Watch, drug traffickers from the Juárez Cartel were helping ISIS members to cross the U.S. border. ${ }^{13}$ However, the Mexican government rejected and categorically denied the report of the Judicial Watch.

Latin America and the Caribbean can provide the Islamic State support in the form of foreign fighters. U.S. intelligence estimates that more than 30,000 foreign fighters from roughly 100 different countries have joined ISIS from 2011, mainly from Tunisia, Saudi Arabia, Russia (Chechnya), Turkey and Jordan. They receive better treatment than their local and conscripted counterparts (Gibbons-Neff 2016). According to press reports, Syrian ISIS fighters receive salaries of about $\$ 200$ a month, but foreign fighters can count on the monthly income of $\$ 400 .{ }^{14}$ U.S. Southern Command General John F. Kelly estimates that about 100 Caribbean natives have traveled into Syria to join ISIS. They come from Jamaica, Trinidad and Tobago, Suriname and Venezuela (Mosendz 2015). But also 23 Argentines and three Brazilians have joined the Islamic State. ${ }^{15}$ After returning they can carry out the terrorist attacks like in Paris and Brussels.

Brazilian intelligence agency also reports the Islamic State wants to recruit the young Brazilian as the lone wolves. The lone-wolf terrorist carries out the violent acts alone, but may be influenced by the ideology of an external group. Brazilian authorities especially fear the terrorists attacks during the Olympic Games in 2016. ${ }^{16}$

${ }^{12}$ Shaikhzadeh Vahdat Ferreira M. A., Hezbollah y la Triple Frontera, Defensa \& Seguridad, http://www.defonline.com.ar/?p=22092, access 6.04.2016.

${ }^{13}$ ISIS Camp a Few Miles from Texas, Mexican Authorities Confirm, 14.04.2015, http://www. judicialwatch.org/blog/2015/04/isis-camp-a-few-miles-from-texas-mexican-authorities-confirm/, access 6.11.2015.

${ }^{14}$ Islamic State to halve fighters' salaries as cost of waging terror starts to bite, "The Guardian", 20.01.2016, http://www.theguardian.com/world/2016/jan/20/islamic-state-to-halve-fighters-salaries-as-cost-of-waging-terror-starts-to-bite, access: 27.04.2016.

${ }^{15}$ Brasileños y argentinos harían parte de ISIS, según reporte, CNN, 10.12.2015, http://cnnespanol. cnn.com/2015/12/10/informe-brasilenos-y-argentinos-hacen-parte-de-isis/, access: 28.04.2016.

${ }^{16}$ Brasil preocupado por reclutamiento de jóvenes por parte del EI, "EL Pais" 21.03.2015. http://www.elpais.com.uy/mundo/brasil-preocupado-reclutamiento-jovenes-yihadistas.html, access: 28.04.2016.
The relations between Latin America and the Islamic State of Iraq and the Levant

Edyta Chwiej 
The growing number of refugees in Latin America is an indirect result of the ISIS activity. The United Nations Office for the Coordination of Humanitarian Affairs estimates that over 250,000 people have been killed from the beginning of the conflict in Syria, 4.8 million Syrians have been forced to leave the country, and 6.6 million are internally displaced. ${ }^{17}$ The vast majority of the refugees is staying in camps in neighboring countries like Turkey (about 2.7 million), Lebanon (about 1 million), Jordan $(643,000)$, Iraq $(246,000)$ and Egypt $(120,000){ }^{18}$ Some of them are trying to get into the European Union, mainly to Germany. But it is also estimated that since 2011 about 6,000 refugees from Syria have arrived in Latin American countries, such as Uruguay, Brazil, Argentina and Chile. ${ }^{19}$ Latin American governments are trying to help Syrian refugees, for example, in 2015 Argentina's government announced the special program that will grant visa to refugees from Syria, with the approval of a three-year stay. ${ }^{20} \mathrm{An}$ other example - since 2013 Brazilian consulates in the Middle East have been issuing special visas under simplified procedures to people affected by the Syrian conflict to travel to Brazil. In 2015 the programme introducing the fast-track applications was extended for another two years. ${ }^{21}$ It is worth mentioning that the countries of the Middle East have a long tradition of migration to Latin America and the Caribbean region - the first migrants from the area of the modern-day Syria came in the second half of the 19th century.

The governments of Latin American states differ in their approach to the fight against the Islamic State. It was visible especially during the 69th session of the United Nations General Assembly (September 2014). During his speech the American president Barack Obama said the Islamic State poses a major threat to global security and called to create a large international coalition to fight against it. Latin American delegations also expressed their points of views. Most of them condemned the Islamic States' terror acts. But they announced the participation in the fight against terrorism within the solutions already adopted at international forum. ${ }^{22}$

The president of Argentina, Cristina Fernández de Kirchner, said the dialogue was essential in the context of solving the Middle East problems. She

${ }^{17}$ About the Syria crisis United Nations Office for the Coordination of Humanitarian Affairs http://www.unocha.org/syrian-arab-republic/syria-country-profile/about-crisis, access: 12.03.2016.

${ }^{18}$ Syria - Regional Refugee Response, United Nations Commission on Human Rights, http:// data.unhcr.org/syrianrefugees/regional.php, access: 12.03.2016.

${ }^{19}$ ¿Qué hacen los países latinoamericanos por los refugiados sirios?, "El Observador" 04.09.2015, http://www.elobservador.com.uy/que-hacen-los-paises-latinoamericanos-los-refugiados-sirios-n674824, access: 7.12.2015.

${ }^{20}$ Argentina otorgará visado para refugiados sirios, Telesur, 04.09.2015, http://www.telesurtv.net/news/Argentina-otorgara-visado-para-refugiados-sirios-20150904-0019.html, access: 7.04.2016.

${ }^{21}$ Brazil and UNHCR strengthen partnership to help refugees fleeing the Syria conflict, UNHCR, 07.10.2015, http://www.unhcr.org/5615130c6.html, access: 28.04.2016.

${ }^{22} 69$ General Assembly 24-30 September 2014, United Nations, http://www.un.org/en/ga/69/ meetings/gadebate/24sep/, access: 29.04.2016. 
pointed out that the countries which had provided weapons to the jihadist groups are responsible for the situation in this region. She added the groups have grown in strength and now the international coalition has to fight against them. Remembering the attack on the Israeli Embassy, she said that Argentina had also experienced political terrorism. Moreover, she accused private financial funds of the sin of speculation, debt problems of developing countries and creation of poverty. She called these actions as economic terrorism.

The Brazilian president Dilma Vana Rousseff also criticized the US policy in the Middle East. The president opposed the use of force against the Islamic State. She said that it did not eliminate the causes of conflicts. President Rousseff pointed out that the conflicts in Palestine, Iraq, Libya, Syria and Ukraine show that military interventions do not lead to peace, but to a deterioration of the conflicts. ${ }^{23}$

By contrast, the Mexican president Enrique Peña Nieto declared that his country would take part in the United Nations peacekeeping missions, for the first time in history. On September 10, 2014, President Obama announced the formation of a global coalition against the Islamic State. According to the U.S. State Department, there are currently 66 participants, including only one country from Latin America and Caribbean region - Panama (McInnis 2016). There were also reports that Mexico was a member of this coalition, but Mexican authorities denied. ${ }^{24}$ However, on November 19, 2014, ISIS published the threats against the countries which had joined the US-led coalition. In a video, Islamic States showed a flag of Mexico within the coalition countries, considering it an ally of the international coalition. ${ }^{25}$

Although there are not many links between the Islamic State and the region of Latin America and the Caribbean, we can say that they really exist. The future relations depend mainly on the effectiveness of the international community in its fight against the expansion of ISIS.

\section{Bibliography}

69 General Assembly 24-30 September 2014, United Nations, http://www.un.org/en/ga/69/ meetings/gadebate/24sep/, access: 29.04.2016.

About the Syria crisis United Nations Office for the Coordination of Humanitarian Affairs http:// www.unocha.org/syrian-arab-republic/syria-country-profile/about-crisis, access: 12.03.2016.

Alexander Y., Alexander D. (2015), The Islamic State. Combating the Caliphate Without Borders, Lexington Books.

\footnotetext{
${ }^{23}$ Ibidem.

${ }^{24}$ SRE niega participación de México en coalición contra ISIS, Aristegui Noticias, 30.09.2014, http://aristeguinoticias.com/3009/mexico/sre-niega-participacion-de-mexico-en-coalicioncontra-isis/, access: 29.04.2016.

${ }^{25}$ México, ¿bajo la amenaza terrorista de ISIS?, CNN 30.11.2015, http://cnnespanol.cnn. com/2015/11/30/tiene-mexico-una-amenaza-terrorista-de-isis/, access: 29.04.2016.
}

The relations between Latin America and the Islamic State of Iraq and the Levant

Edyta Chwiej 
Argentina otorgará visado para refugiados sirios, Telesur, 04.09.2015, http://www.telesurtv.net/ news/Argentina-otorgara-visado-para-refugiados-sirios-20150904-0019.html, access: 07.04.2016.

Brazil and UNHCR strengthen partnership to help refugees fleeing the Syria conflict, UNHCR, 07.10.2015, http://www.unhcr.org/5615130c6.html, access: 28.04.2016.

Brasil preocupado por reclutamiento de jóvenes por parte del EI, "El País", 21.03.2015, http:// www.elpais.com.uy/mundo/brasil-preocupado-reclutamiento-jovenes-yihadistas.html, access: 28.04.2016.

Brasileños y argentinos harían parte de ISIS, según reporte, CNN, 10.12.2015, http:// cnnespanol.cnn.com/2015/12/10/informe-brasilenos-y-argentinos-hacen-parte-de-isis/, access: 28.04.2016.

Cockburn P. (2015), Państwo Islamskie, PWN, Warszawa.

Country Reports on Terrorism 2014, U.S. Department of State, http://www.state.gov/j/ct/rls/ crt/2014/index.htm, access: 26.03.2016.

Dearden L., Isis 'loses 40\% of Iraq territory and 20\% in Syria' as international air strikes support ground operations, "The Independent", 5.01.2016, http://www.independent.co.uk/news/ world/middle-east/isis-loses-40-of-iraq-territory-and-20-in-syria-as-international-airstrikes-support-ground-a6797486.html, access: 21.03.2016.

Gibbons-Neff T., Number of foreign fighters entering Iraq and Syria drops by 90 percent, Pentagon says, "The Washington Post", 26.04.2016, https://www.washingtonpost.com/news/ checkpoint/wp/2016/04/26/number-of-foreign-fighters-entering-iraq-and-syria-drops-by90-percent-pentagon-says/, access: 27.04.2016.

Hall B. (2015), ISIS. Państwo Islamskie, Muza, Warszawa.

Harvey D., Pregent M., Who's to blame for Iraq crisis, 12.06.2014, http://edition.cnn. com/2014/06/12/opinion/pregent-harvey-northern-iraq-collapse/, access: 10.03.2016.

Irshaid F., Isis, Isil, IS or Daesh? One group, many names, 2.12.2015, http://www.bbc.com/ news/world-middle-east-27994277, access: 17.03.2016.

ISIS Camp a Few Miles from Texas, Mexican Authorities Confirm, 14.04.2015, http://www. judicialwatch.org/blog/2015/04/isis-camp-a-few-miles-from-texas-mexican-authoritiesconfirm/, access: 6.11.2015.

ISIS. Organizational Structure, Counter Extremism Project, http://www.counterextremism. com/threat/isis, access: 18.03.2016.

ISIS under airstrikes - a guide in maps, “The Guardian", 2.12.2015, http://www.theguardian. com/world/ng-interactive/2015/dec/02/isis-territory-under-airstrikes-guide-in-maps, access: 14.03.2016.

Islamic State group: Crisis in seven charts, 15.03.2016, http://www.bbc.com/news/worldmiddle-east-27838034, access: 18.03.2016.

Islamic State in Iraq and the Levant (ISIL), Encyclopedia Britannica, http://www.britannica. com/topic/Islamic-State-in-Iraq-and-the-Levant, access: 10.03.2016.

Islamic State to halve fighters' salaries as cost of waging terror starts to bite, "The Guardian", 20.01.2016, http://www.theguardian.com/world/2016/jan/20/islamic-state-to-halve-fighterssalaries-as-cost-of-waging-terror-starts-to-bite, access: 27.04.2016.

Jones S., Saleh H., Isis in Libya: Stoking conflict, “The Financial Times”, 20.03.2016, http:// www.ft.com/intl/cms/s/0/c06fb0d6-e1f7-11e5-8d9b-e88a2a889797.html\#axzz46ottd9vR, access: 25.04.2016. 
Klausner A., US Prison camp in Iraq accidentally formed ISIS by housing the most radical jihadists together and allowing them to organize terror group, "Daily Mail" 31.05.2015, http:// www.dailymail.co.uk/news/article-3104859/US-Prison-camp-Iraq-accidentally-formedISIS-housing-radial-jihadists-allowing-organize-terror-group.html, access: 18.03.2016.

Kurth Cronin A., ISIS Is Not a Terrorist Group, "Foreign Affairs", III/IV.2015, https://www. foreignaffairs.com/articles/middle-east/isis-not-terrorist-group, access: 21.03.2016.

Laub Z., The Islamic State, The Council on Foreign Relations, http://www.cfr.org/iraq/islamicstate/p14811, access: 10.03.2016,

Laurent S. (2015), Kalifat terroru, Foksal, Warszawa.

López I., El Estado Islámico voltea hacia América Latina, “Excélsior”, 22.02.2015, http://www. excelsior.com.mx/global/2015/02/22/1009648, access: 04.11.2015.

Mauro R., ISIS Has up To 42 Million Supporters in the Arab World, The Clarion Project, 28.VI.2015, http://www.clarionproject.org/analysis/isis-has-least-42-million-supporters-arabworld\#, access: 24.04.2016.

McInnis K., Coalition Contributions to Countering the Islamic State, Congressional Research Service Report, 13.04.2016, https://www.fas.org/sgp/crs/natsec/R44135.pdf, access: 29.04.2016.

México, ¿bajo la amenaza terrorista de ISIS?, CNN 30.11.2015, http://cnnespanol.cnn. com/2015/11/30/tiene-mexico-una-amenaza-terrorista-de-isis/, access: 29.04.2016.

Mosendz P., General Warns of ISIS Fighters Entering U.S. Through Caribbean, "Newsweek", 13.03.2015, http://europe.newsweek.com/general-warns-isis-fighters-entering-us-throughcaribbean-313807? rm=eu, access: 27.04.2016.

Noack R., Here's how the Islamic State compares with real states, "The Washington Post", 12.09.2014, https://www.washingtonpost.com/news/worldviews/wp/2014/09/12/heres-howthe-islamic-state-compares-to-real-states/, access: 18.03.2016.

Osborne S., Isis vs. Daesh vs. Isil vs Islamic State: What do the different names mean and why are there so many?, "The Independent", 03.12.2015, http://www.independent.co.uk/news/ world/middle-east/isis-vs-daesh-vs-isil-vs-islamic-state-what-do-the-names-mean-andwhy-are-there-so-many-a6759106.html, access: 17.03.2015.

Profile: Abu Bakr al-Baghdadi, 15.05.2015, http://www.bbc.com/news/world-middleeast-27801676, access: 17.03.2016.

¿Qué hacen los países latinoamericanos por los refugiados sirios?, "El Observador” 04.09.2015, http://www.elobservador.com.uy/que-hacen-los-paises-latinoamericanos-los-refugiadossirios-n674824, access: 07.12.2015.

Shaikhzadeh Vahdat Ferreira M.A., Hezbollah y la Triple Frontera, Defensa \& Seguridad, http://www.defonline.com.ar/?p=22092, access: 06.04.2016.

SRE niega participación de México en coalición contra ISIS, Aristegui Noticias, 30.09.2014, http://aristeguinoticias.com/3009/mexico/sre-niega-participacion-de-mexico-en-coalicioncontra-isis/, access: 29.04.2016.

Sunni rebels declare new 'Islamic caliphate, "Al-Jazzera", 30.06.2014, http://www.aljazeera. com/news/middleeast/2014/06/isil-declares-new-islamic-caliphate-201462917326669749. html, access: 14.03.2016.

Swanson A., How the Islamic State makes its money, "The Washington Post", 18.11.2015, https://www.washingtonpost.com/news/wonk/wp/2015/11/18/how-isis-makes-its-money/, access: 21.03.2016.
The relations between Latin America and the Islamic State of Iraq and the Levant

Edyta Chwiej 
Syria - Regional Refugee Response, United Nations Commission on Human Rights, http:// data.unhcr.org/syrianrefugees/regional.php, access: 12.03.2016.

Syria: The story of the conflict, BBC, 11.11.2016, http://www.bbc.com/news/world-middleeast-26116868, access: 12.03.2016.

Thompson N., Shubert A., The anatomy of ISIS: How the 'Islamic State' is run, from oil to beheadings, 14.01.2015, CNN, http://edition.cnn.com/2014/09/18/world/meast/isis-syriairaq-hierarchy/, access: 18.03.2016.

Weawer M, Isis declares caliphate in Iraq and Syria, "The Guardian", 30.06.2014, http://www. theguardian.com/world/middle-east-live/2014/jun/30/isis-declares-caliphate-in-iraq-andsyria-live-updates, access: 10.03.2016.

Withnall A., Blair O., Abu Bakr al-Baghdadi: Five things we know about the ISIS leader, "The Independent", 12.10.2015, http://www.independent.co.uk/news/world/middle-east/five-thingswe-do-know-about-isis-leader-abu-bakr-al-baghdadi-a6689716.html, access: 17.03.2016. 